\title{
ANALISIS VECTOR AUTOREGRESION (VAR) TERHADAP INTERRELATIONSHIP ANTARA IPM DAN PERTUMBUHAN EKONOMI DI SUMATERA UTARA
}

\author{
MASTA SEMBIRING \\ Dosen Fakultas Ekonomi Universitas Muhammadiyah Sumatera Utara \\ email : azthabiring80@gmail.com
}

\begin{abstract}
ABSTRAK
Tujuan dari penelitian ini adalah untuk mengetahui hubungan antara indeks pembangunan manusia (IPM) dan pertumbuhan ekonomi kabupaten / kota di provinsi Sumatera Utara selama periode 2003-2014. Penelitian ini menggunakan data panel dan uji kointegrasi untuk melihat hubungan jangka panjang antara indeks pembangunan manusia dan pertumbuhan ekonomi dengan menggunakan program eviews 6 .

Dari hasil uji kointegrasi menunjukkan hubungan ekuilibrium jangka panjang antara Indeks pembangunan manusia dan pertumbuhan ekonomi.
\end{abstract}

\section{Kata kunci : Indeks pembangunan manusia, Pertumbuhan penduduk}

\section{A. PENDAHULUAN}

Setiap bangsa dari negara yang merdeka dan berdaulat berkeinginan untuk hidup sejahtera dan sejajar dengan bangsa-bangsa lainnya. Untuk mencapai kehidupan yang sejahtera, penduduk negara tersebut dengan segala potensi yang tersedia melakukan upaya pembangunan ke arah yang lebih baik. Pada awalnya upaya pembangunan negara yang sedang berkembang diidentikkan dengan upaya meningkatkan pendapatan perkapita atau disebut juga dengan strategi pertumbuhan ekonomi. Dengan ditingkatkannya pendapatan perkapita, diharapkan masalah-masalah pengangguran, kemiskinan, dan ketimpangan distribusi pendapatan yang dihadapi negara yang sedang berkembang dapat terpecahkan.

Sejalan dengan berjalanannya waktu, disadari bahwa pertumbuhan ekonomi yang tinggi tidak serta merta dapat mengatasi masalah pengangguran, kemiskinan di perdesaan, distribusi pendapatan yang timpang. Hal ini memperkuat keyakinan bahwa pertumbuhan ekonomi merupakan syarat yang diperlukan (necessary), tetapi tidak mencukupi (sufficient) bagi proses pembangunan ( Esmara, Meier dalam Kuncoro, 2010 ).Untuk menyempurnakan tujuan pembangunan tersebut, munculah konsep pembangunan manusia.

Menurut UNDP (1990) mengenai pembangunan manusia ialah suatu proses memperluas pilihan-pilihan penduduk (a process Enlarging people's choices). Ada tiga pilihan yang dianggap paling penting, yaitu panjang umur dan sehat (longevity), berpendidikan/berpengetahuan (knowledge), dan akses ke sumber daya yang dapat memenuhi standar hidup yang layak (living standard).

Berdasarkan latar belakang yang telah uraikan diatas, maka penulis tertarik untuk melakukan penelitian yang berjudul "Analisis vector autoregresion (VAR) terhadap interrelationship antara IPM dan pertumbuhan ekonomi di Sumatera Utara." 
Tujuan dari penelitian ini adalah Untuk untuk mengetahui pola hubungan antara IPM dengan pertumbuhan ekonomi di Sumatera Utara, serta untuk mengetahui hubungan kointegrasi antara IPM dan pertumbuhan ekonomi di kabupaten/kota di Provinsi Sumatera Utara.

\section{B. TINJAUAN PUSTAKA}

\section{Pengertian Pembangunan Manusia}

Menurut UNDP (1990) Pembangunan manusia ialah proses memperluas pilihan-pilihan penduduk (a process enlarging people's choices), dan tiga pilihan utama yang dianggap paling penting, yaitu diantaranya adalah panjang umur dan sehat (longevity), berpendidikan/berpengetahuan (knowledge), dan akses ke sumber daya yang dapat memenuhi standar hidup yang layak (living standard).

Peluang hidup yang dimaksudkan ialah peluang hidup yang dihitung berdasarkan angka kehidupan ketika lahir, sementara pengetahuan diukur berdasarkan rata-rata lamanya bersekolah dan angka melek huruf penduduk yang berusia 15 tahun ke atas, sedangkan hidup yang layak yang dimaksudkan ialah diukur dengan pengeluaran per-kapita yang didasarkan oleh paritas daya beli (purchasing power parity).

Ada tiga komponen utama dalam IPM yaitu :

- Panjang Umur dan Sehat

Dimana kesehatan dianggap penting dan merupakan bagian integral dari pembangunan Nasional. Kesehatan juga dipengaruhi oleh banyak faktor, diantaranya: lingkungan, perilaku sehat, serta pelayanan kesehatan yang baik. Keadaan kesehatan masyarakat juga dapat diukur melalui angka kematian, status gizi, angka kesakitan, serta usia hidup seseorang. Untuk mewujudkan hal tersebut berbagai usaha-usaha yang dapat dilakukan antara lain, seperti: penyuluhan kesehatan, penyediaan fasilitas kesehatan, misalnya: Puskesmas, klinik bersalin, penyediaan air bersih, dan sebagainya.

- Berpendidikan/Berpengetahuan

Pendidikan merupakan sarana untuk meningkatkan kualitas sumber daya manusia, melalui pendidikan dapat meningkatkan pengetahuan dan ketrampilan. Dalam hal ini, pendidikan mendukung pertumbuhan ekonomi. Pendidikan merupakan investasi jangka panjang untuk mencapai suatu target pekerjaan yang lebih layak dengan pendapatan yang dapat menunjang kehidupan kearah yang lebih sejahtera.

- Standar Hidup yang Layak

Pengeluaran per kapita riil merupakan suatu ukuran pendapatan yang disesuaikan dengan paritas daya beli. Variabel ini dipergunakan untuk mengukur kemampuan masyarakat dalam mengakses sumber daya ekonomi secara luas (daya beli). Variabel ini sangat penting, karena dapat mempengaruhi derajat kesehatan masyarakat untuk meningkatkan usia harapan hidup, serta memproleh pendidikan yang lebih baik. Tingkat kesejahteraan dikatakan meningkat, apabila pengeluaran riil per kapita meningkat pula.

\section{Faktor - Faktor yang Menentukan Pertumbuhan Ekonomi}

Proses pertumbuhan ekonomi dipengaruhi oleh dua macam faktor yang terdiri dari faktor ekonomi dan faktor non ekonomi. Faktor ekonomi mencakup sumber alam atau tanah, akumulasi modal, organisasi, dan kemajuan tekhnologi, sedangkan faktor non ekonomi seperti sumberdaya manusia dan faktor politik dan administratif. 


\section{METODE PENELITIAN}

\section{Ruang Lingkup Penelitian}

Penelitian ini mengkaji analisis indeks pembangunan manusia (IPM) dan pertumbuhan ekonomi di Sumatera Utara (Metode Kointegrasi) selama kurun waktu 2003 - 2014. Ruang lingkup penelitian ini dilakukan di Sumatera Utara.

\section{Jenis dan Sumber Data}

Data yang diperlukan pada penelitian ini adalah data skunder yang diperoleh dari buku-buku, jurnal, internet, penelitian terdahulu, catatan-catatan, dan sumber lainnya yang berhubungan dengan masalah penelitian. Data sekunder sendiri merupakan data yang telah tersedia dan juga telah diproses oleh pihak-pihak lain sebagai hasil atas penelitian terdahulu.

\section{Metode Estimasi}

Permasalahan dalam studi ini akan dianalisis dengan memakai vector Autoregression. Secara sederhana, VAR menggambarkan hubungan yang" saling menyebabkan "( kausalistis) antar variabel dalam system, dengan menambahkan intercept.

\section{a. uji Stationeritas}

Data ekonomi time series umumnya bersifat stokastik atau memiliki tren yang tidak stationer, artinya data tersebut memiliki akar unit. Untuk dapat mengstimasi suatu model penggunaan data tersebut langkah pertama yang harus dilakukan adalah pengujian stasioneritas data atau dikenal unit root test .) Gujarati, 2003)

\section{b. pemilihan lag optimum}

Penentuan jumlah lag ( ordo) yang akan digunakan dalam model VAR dapat ditentukan berdasarkan kriteria Akaike Information Criterion (AIC) dan Schwarz Information Criterion (SC). Lag yang akan dipilih dalam penelitian ini adalah model dengan nilai AIC yang paling kecil. Dalam tahapan ini pula dilakukan uji stabilitas model VAR. penentuan lag optimum dan uji stabilitas VAR dilakukan terlebih dahulu sebelum melalui tahap uji kointegrasi.

\section{c. Uji stabilitas}

Untuk menguji stabilitas atau tidaknya estimasi VAR yang telah dibentuk maka dilakukan pengecekan kondisi VAR stability berupa roots of characteristic polynominal. Suatu system VAR dilakukan stabil apabila seluruh rootsnya memiliki modulus lebih kecil dari satu (Gujarati, 2003).

\section{d. Uji Kointegrasi}

Jika fenomena stasionaritas berada pada tingkat fisrt difference atau I(1), maka perlu dilakukan pengujian untuk melihat kemungkinan terjadinya kointegrasi. Konsep kointegrasi pada dasarnya untuk melihat keseimbangan jangka panjang diantara variabel-variabel yang diobservasi. Terkadang suatu data yang secara individu tidak stasioner, namun ketika dihubungkan secara linier data tersebut menjadi stasioner, namun ketika dihubungkan secara linier data tersebut menjadi stasioner. Hal ini yang kemudian disebut bahwa data tersebut terkointegrasi. Apabila satu set variabel benar-benar terkointegrasi, maka harus dapat dideteksi implied restiriksi atau unrestriksi VAR (Green, 2000 : 794). 


\section{e. Vector error correction model (vecm)}

VECM adalah bentuk vector Autoregression yang terestriksi. Restriksi tambahan ini harus diberikan karena keberadaan bentuk data yang tidak stasioner namun terkointegrasi. VECM kemudian memanfaatkan informasi restriksi kointegrasi tersebut ke dalam spesifikasinya. Karena itulah VECM sering disebut desain VAR bagi series nonstasioner yang memiliki hubungan kointegrasi (Tanjung dan Devi, 2013:269).

\section{f. Instrument vector Autoregression.}

Dalam melakukan analisisnya, VAR memiliki instrument spesifik yang memiliki fungsi spesifik dalam menjelaskan interaksi antarvariabel dalam model. Instrument itu meliputi Impulse Response Function (IRF)dan forecast Error variance Decompisitions (FEVD), atau biasa disebut variance Decompisition $(V D)$. IRF merupakan aplikasi vector moving average yang bertujuan melihat seberapa lama goncangan dari satu variabel berpengaruh terhadap variabel lain. Sedangkan VD dalam VAR berfungsi untuk menganalisis seberapa besar goncangan dari sebuah variabel mempengaruhi variabel lain.

\section{PEMBAHASAN}

\section{Uji Stasioner Data}

Uji stasioner data dapat dilakukan dengan metode grafik dan metode akar unit. Uji akar unit digunakan uji augmented Dickey-fuller (ADF) jika nilai absolute statistic t lebih kecil dari nilai kritis pada table MacKinnon pada berbagai tingkat kepercayaan $(1 \%, 5 \%$ dan $10 \%)$. Maka mengindikasikan data tidak stationer. Disamping itu dapat pula dilihat pada nilai prob yang lebih besar dari 0,05 yang juga menindikasikan data tidak stationer (Winarno, 2007, 11-4). Sebaliknya jika nilai ADF lebih besar dari nilai kritis berbagai tingkat kepercayaan (1\%, 5\%. Dan 10\%), maka tidak terdapat akar unit atau data stationer.

\section{Tabel 1}

Hasil ujo ADF

\begin{tabular}{|l|l|l|l|l|l|}
\hline Variabel & Unit Root & $\begin{array}{l}\text { Include in } \\
\text { test equation }\end{array}$ & $\begin{array}{l}\text { ADF Test } \\
\text { Statistic }\end{array}$ & $\begin{array}{l}\text { Critical } \\
\text { Value 5\% }\end{array}$ & keterangan \\
\hline \multirow{4}{*}{ IPM } & Level & Intercept & -2.886101 & -3.145590 & Stationer \\
\cline { 2 - 6 } & First Diff & Intercept & -1.995865 & -3.145590 & Stationer \\
\cline { 2 - 6 } & Second Diff & Intercept & -1599088 & -3.145590 & Stationer \\
\hline \multirow{2}{*}{$\begin{array}{l}\text { Pertumbuhan } \\
\text { Ekonomi }\end{array}$} & Level & Intercept & -2.792154 & -3.145590 & Stationer \\
\cline { 2 - 6 } & First Diff & Intercept & -1.977738 & -3.145590 & Stationer \\
\cline { 2 - 6 } & Second Diff & Intercept & -1.602074 & -3.145590 & Stationer \\
\hline
\end{tabular}

Dari tabel 1 dapat dijelaskan bahwa nilai ADF test untuk suku IPM lebih kecil dari nilai kritis 5\% artinya sudah stationer baik pada level maupun pada first different dan second different. Demikian juga Pertumbuhan Ekonomi variabel sudah stationer pada tingkat level, first different maupun second different.

\section{Uji Panjang Lag Optimal}

Pendekatan VAR sangat sensitive terhadap jumlah lag data yang digunakan, oleh karenanya perlu ditetapkan panjang lag yang optimal. Penentuan panjang lag tersebut dimanfaatkan untuk mengetahui lamanya periode keterpengaruhan terhadap 
suatu variabel endogen dengan pada waktu waktu yang lalu maupun terhadap variabel endogen lainnya.

Penentuan panjang lag dapat dilihat dari nilai-nilai dari likelihood ratio (LR), final prediction error (FPE), akaike information criterion (AIC) dan Schwarz information (SC). Nilai-nilai dapat dilihat dari table 2 hasil uji panjang lag optimal dibawah ini.

Tabel 2

VAR Lag Order Selection Criteria

\section{Hasil Uji Panjang Lag Optimum}

Endogenous variables: IPM PERTUMBUHAN_EKONOMI

Exogenous variables: $\mathrm{C}$

Date: 12/14/16 Time: 16:54

Sample: 20032014

Included observations: 10

\begin{tabular}{ccccccc}
\hline \hline Lag & LogL & LR & FPE & AIC & SC & HQ \\
\hline \hline 0 & -31.53463 & NA $^{*}$ & 2.808116 & 6.706926 & 6.767443 & 6.640539 \\
1 & -29.75424 & 2.492550 & 4.541113 & 7.150848 & 7.332399 & 6.951687 \\
2 & -21.34171 & 8.412527 & $2.202985^{*}$ & $6.268343^{*}$ & $6.570928^{*}$ & $5.936407^{\star}$ \\
\hline \hline
\end{tabular}

* indicates lag order selected by the criterion

LR: sequential modified LR test statistic (each test at $5 \%$ level)

FPE: Final prediction error

AIC: Akaike information criterion

SC: Schwarz information criterion

$\mathrm{HQ}$ : Hannan-Quinn information criterion

Dari tabel 2 tersebut, nilai lag terdapat pada lag 2, dimana pada lag ini terhimpun nilai terendah bagi final prediction error(FPE) dan akaike information criterion (AIC). Adapun Schwarz information criterion (SC) nilai terendah terdapat pada lag 2. Hannan-Quinn informationcriterion $(H Q)$ titik terendah terdapat pada lag 2.Oleh karenanya panjang lag optimumnya berada pada lag 2 .

\section{Hasil Uji Stabilitas VAR}

Untuk menguji stabil atau tidaknya estimasi VAR yang telah ditentukan maka dilakukan VAR condition stability check yakni berupa roots of characteristic polynominal. Suatu model VAR dikatakan stabil jika seluruh roots nya memiliki modulus lebih kecil dari 1 Gujarati,2003).

Berikut ini hasil uji stabilitas VAR yang disajikan dalam table berikut ini:

\section{Tabel 3}

\section{Hasil Uji Stabilitas Model}

Roots of Characteristic Polynomial

Endogenous variables: IPM PERTUMBUHAN_EKONOMI

Exogenous variables: $\mathrm{C}$

Lag specification: 12

Date: $12 / 14 / 16$ Time: 16:22

\begin{tabular}{cc}
\hline \hline Root & Modulus \\
\hline \hline $0.205378-0.730656 \mathrm{i}$ & 0.758972 \\
$0.205378+0.730656 \mathrm{i}$ & 0.758972
\end{tabular}



$-0.127150-0.320119 \mathrm{i}$
0.344447
$-0.127150+0.320119 i$
0.344447

No root lies outside the unit circle.

VAR satisfies the stability condition

Dari tabel diatas terlihat bahwa tidak ada nilai akar karakteristik dan modulus yang lebih dari 1. Sedangkan dari gambar 1 . Terlihat bahwa titik invers roots of $A R$ polynomial semuanya berada didalam lingkaran.

Inverse Roots of AR Characteristic Polynomial

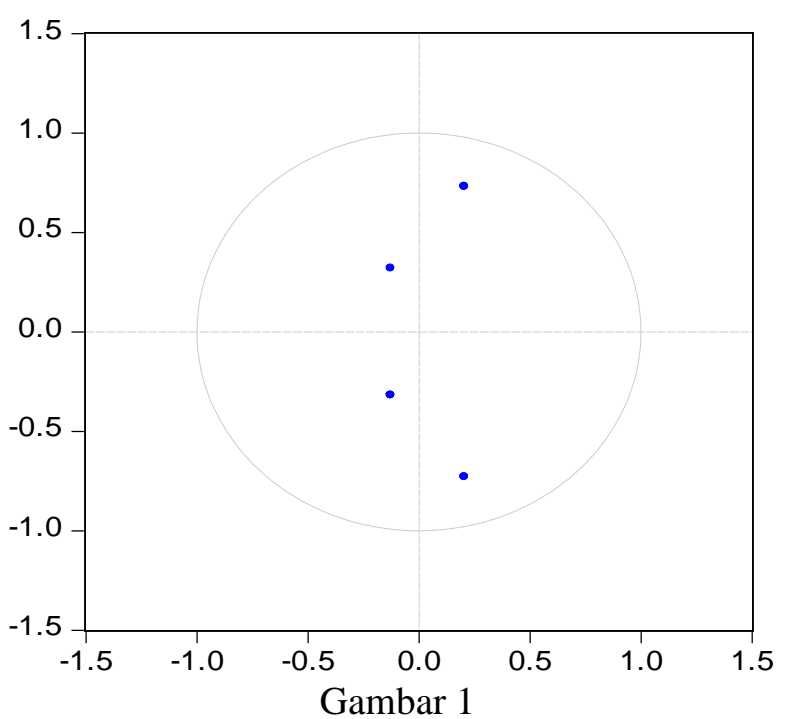

Hasil uji Stabilitas VAR

\section{Hasil Analisis causality granger}

Uji kausalitas granger antarvariabel penelitian dimaksud untuk mengetahui hubungan kausalitas antara variabel (Nachrowi, 2006:289). Dari tabel berikut ini hasil uji tersebut dapat diketahui adanya hubungan timbal balik.

Tabel 4

Painise Granger Causality Tests

\section{Hasil Uji Granger Kausaliti}

Date: 12/14/16 Time: 16:28

Sample: 20032014

Lags: 2

\begin{tabular}{lccc}
\hline \hline Null Hypothesis: & Obs & F-Statistic & Prob. \\
\hline \hline PERTUMBUHAN EKONOM does not Granger Cause IPM & 10 & 5.35968 & 0.0571 \\
IPM does not Granger Cause PERTUMBUHAN_EKONOM & & 4.06257 & 0.0896 \\
\hline
\end{tabular}

Pada tabel 4 semua variabel tidak memiliki hubungan timbal balik atau tidak memiliki hubungan dua arah signifikan pada level 5\% (probability $>0,05$ ) pada lag 2. Artinya bahwa IPM 2 periode yang lalu tidak mempengaruhi secara signifikan terhadap pertumbuhan ekonomi. 


\section{Hasil Uji Kointegrasi}

Kointegrasi berarti terdapat hubungan jangka panjang (keseimbangan). Dalam jangka pendek dan kemungkinan terjadi ketidakseimbangan (disekuilibrium). Karena adanya ketidak seimbangan ini maka diperlukan adanya koreksi dengan model koreksi kesalahan (error correction Model) yang diperkenalkan sarga, dikembangkan Hendry dan dipopulerkan Engle dan Granger (Winarno, 2006:11.7-11.9). Ada tiga cara menguji kointegrasi, yaitu 1) Uji Kointegrasi Engle Grenger 2) Uji kointegrasi regression Durbin Watson 3) Uji Johansen.

Penelitian ini menggunakan uji johansen, dengan uji johansen, dibandingkan nilai trance statistic dengan nilai kritis pada tingkat keyakinan 5\% maupun $1 \%$. Apabila nilai trance statistic-nya lebih kecil disbanding nilai kritis maka dapat disimpulkan bahwa kedua variabel tidak saling berkointegrasi (Winarno, 2006: 11.7). melalui pengujian kointegrasi Johansen's pada table 5 dibawah ini, tampak nilai trace statistic > critical value pada tingkat keyakinan 5\%. Dengan demikian mengindikasikan kedua variabel saling berkointegerasi. Kointegerasi ini ditunjukkan pula pada catatan dibawah tabel yang berbunyi "Trace test indicates 2 cointegrating eqn(s) at the 0.05 level".

Tabel 5

Uji Kointegrasi Johansen's

Date: 12/14/16 Time: 16:33

Sample (adjusted): 20052014

Included observations: 10 after adjustments

Trend assumption: Linear deterministic trend (restricted)

Series: IPM PERTUMBUHAN_EKONOMI

Lags interval (in first differences): 1 to 1

Unrestricted Cointegration Rank Test (Trace)

\begin{tabular}{ccccc}
\hline \hline $\begin{array}{c}\text { Hypothesized } \\
\text { No. of CE }(\mathrm{s})\end{array}$ & Eigenvalue & $\begin{array}{c}\text { Trace } \\
\text { Statistic }\end{array}$ & $\begin{array}{c}0.05 \\
\text { Critical Value }\end{array}$ & Prob. $^{* *}$ \\
\hline \hline None & 0.811517 & 26.92912 & 25.87211 & 0.0368 \\
At most 1 & 0.640904 & 10.24164 & 12.51798 & 0.1166 \\
\hline \hline
\end{tabular}

Trace test indicates 1 cointegrating eqn(s) at the 0.05 level

* denotes rejection of the hypothesis at the 0.05 level

** MacKinnon-Haug-Michelis (1999) p-values

Unrestricted Cointegration Rank Test (Maximum Eigenvalue)

\begin{tabular}{ccccc}
\hline \hline $\begin{array}{c}\text { Hypothesized } \\
\text { No. of CE(s) }\end{array}$ & Eigenvalue & $\begin{array}{c}\text { Max-Eigen } \\
\text { Statistic }\end{array}$ & $\begin{array}{c}0.05 \\
\text { Critical Value }\end{array}$ & Prob. ** $^{*}$ \\
\hline \hline None & 0.811517 & 16.68748 & 19.38704 & 0.1182 \\
At most 1 & 0.640904 & 10.24164 & 12.51798 & 0.1166 \\
\hline \hline
\end{tabular}

Max-eigenvalue test indicates no cointegration at the 0.05 level

* denotes rejection of the hypothesis at the 0.05 level

${ }^{* *}$ MacKinnon-Haug-Michelis (1999) p-values

Unrestricted Cointegrating Coefficients (normalized by $b^{\prime *} S 11^{*} b=I$ ):

\begin{tabular}{ccc}
\hline & PERTUMBUHAN \\
IPM & EKONOMI @TREND(04)
\end{tabular}




\begin{tabular}{|c|c|c|c|}
\hline $\begin{array}{r}-0.267641 \\
0.532473\end{array}$ & $\begin{array}{r}3.435866 \\
-1.249336\end{array}$ & $\begin{array}{r}-0.084552 \\
0.105330\end{array}$ & \\
\hline \multicolumn{4}{|c|}{ Unrestricted Adjustment Coefficients (alpha): } \\
\hline $\begin{array}{c}\text { D(IPM) } \\
\text { D(PERTUMBUH } \\
\text { AN_EKONOMI) }\end{array}$ & $\begin{array}{l}-0.666651 \\
-0.681583\end{array}$ & $\begin{array}{r}-1.846085 \\
0.018347\end{array}$ & \\
\hline \multicolumn{2}{|c|}{1 Cointegrating Equation(s): } & Log likelihood & -25.69770 \\
\hline \multicolumn{4}{|c|}{ Normalized cointegrating coefficients (standard error in parentheses) } \\
\hline $\begin{array}{c}\text { IPM } \\
1.000000\end{array}$ & $\begin{array}{l}\text { RTUMBUH } \\
\text { EKONOMI } \\
-12.83759 \\
(1.98206)\end{array}$ & $\begin{array}{c}@ T R E N D(04) \\
0.315915 \\
(0.34369)\end{array}$ & \\
\hline \multicolumn{4}{|c|}{ Adjustment coefficients (standard error in parentheses) } \\
\hline $\mathrm{D}(\mathrm{IPM})$ & $\begin{array}{l}0.178423 \\
(0.25439)\end{array}$ & & \\
\hline $\begin{array}{l}\text { D(PERTUMBUH } \\
\text { AN_EKONOMI) }\end{array}$ & $\begin{array}{l}0.182419 \\
(0.03598)\end{array}$ & & \\
\hline
\end{tabular}

Indikator berikutnya bahwa, berdasarkan hasil uji kointegerasi tidak didapati tanda kointegerasi dengan lambing $(*)$ pada at most 1 . Seandainya terdapat ditandai $(* *)$ atau $(*)$ minimal satu, maka persamaan tersebut harus diselesaikan dengan metode VECM (Vector Error Correction Model).

Berdasarkan uji kointegrasi Johansen's terhadap kedua variabel pada system persamaan dapat diketahui jumlah hubungan yang mungkin.

Terlihat pada table diatas bahwa terdapat:

- Pada trace Test mengidentifikasikan terdapat 1 persamaan kointegrasi pada level $5 \%$.

- Pada Max Eigenvalue test mengidentifikasi terdapat persamaan kointegrasi pada level $5 \%$.

Dengan demikian antara variabel IPM dan Pertimbuhan Penduduk terdapat hubungan stabilitas keseimbangan jangka panjang dan pergerakan dalam jangka panjang, Sementara dalam jangka pendek seluruh variabel saling menyesuaikan untuk mecapai keseimbangan jangka panjang.

\section{Analisis Impulse Respon.dan Variance Decomposition}

- Analisis Impulse Respon

Pada gambar 2 diperlihatkan Impulse Respon IPM terhadap IPM, IPM terhadap Pertumbuhan ekonomi, Response pertumbuhan ekonomi terhadap IPM serta respons Pertumbuhan Ekonomi terhadap Pertumbuhan Ekonomi. Pada gambar Response to Cholesky One S.d. innovation terlihat respon IPM terhadap IPM, IPM terhadap Pertumbuhan ekonomi, Response pertumbuhan ekonomi terhadap IPM serta respons Pertumbuhan Ekonomi terhadap Pertumbuhan Ekonomi memiliki kenaikan dan penurunan di setiap periode. 
Response of IPM to IPM

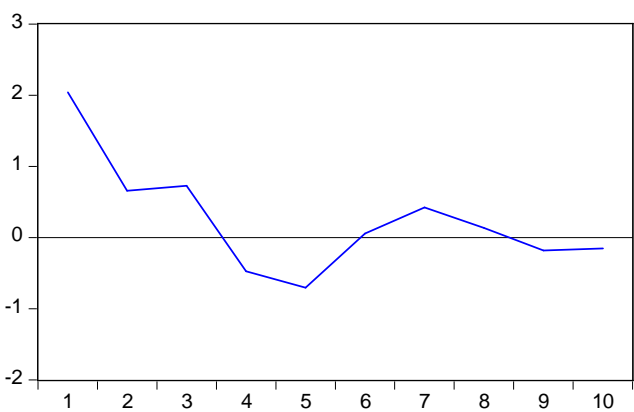

Response of PERTUMBUHAN_EKONOMI to IPM

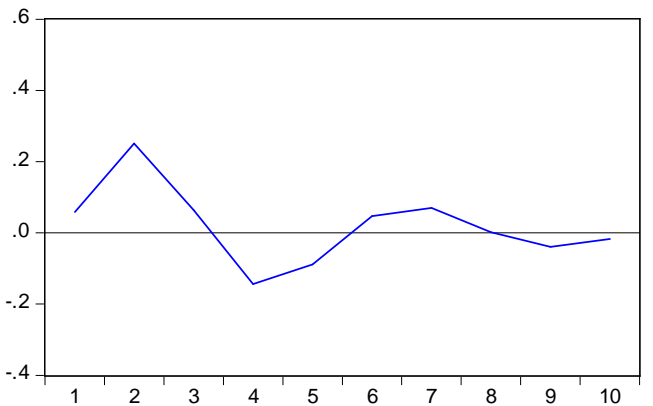

Response of IPM to PERTUMBUHAN_EKONOMI

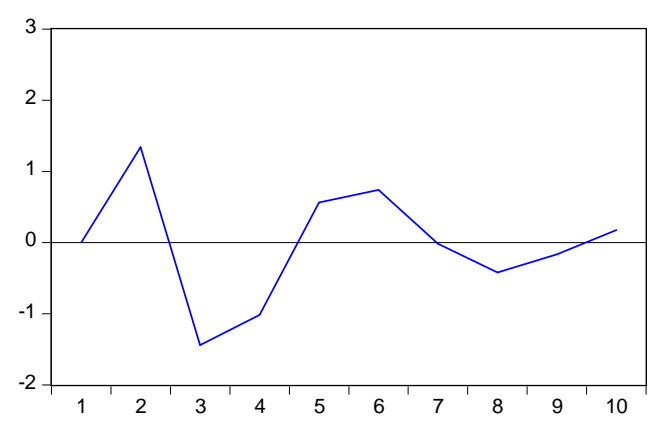

Response of PERTUMBUHAN_EKONOMI to PERTUMBUHAN_EKONOMI

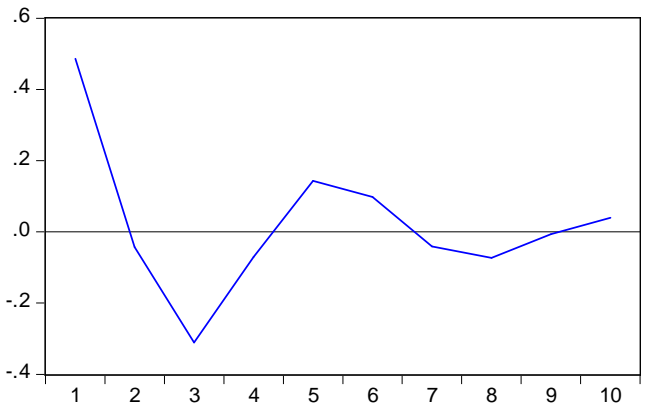

Gambar 2

\section{Respon IPM rethadap different Pertumbuhan ekonomi}

\section{- Analisis Variance Decomposition}

Setelah analisis terhadap perilaku dinamis model melalui impulse respon function, maka selanjutnya akan dilihat karakteristik model melalui Variance Decomposition. Hasil variance decomposition dapat dilihat pada tabel 6 dimana fluktuasi Differen IPM dipengaruhi Pertumbuhan Ekonomi. Pada periode ke dua differen IPM tertinggi 71,84 persen terus menurun sampai periode ke sepuluh menjadi 50,33 persen. Sebaliknya pengaruh bagi hasil mengalami peningkatkan secara berlawanan mulai dari $28,15 \%$ pada periode kedua sampai $49,66 \%$ pada periode ke 10.

Tabel 6

Variance Decompotion

\begin{tabular}{cccc}
\hline \hline \multicolumn{4}{c}{ Variance Decomposition of IPM: } \\
Period & S.E. & IPM & $\begin{array}{c}\text { PERTUMBUHAN } \\
\text { EKONOMI }\end{array}$ \\
\hline \hline 1 & 2.037173 & 100.0000 & 0.000000 \\
2 & 2.525763 & 71.84673 & 28.15327 \\
3 & 2.997700 & 56.85644 & 43.14356 \\
4 & 3.200747 & 52.06695 & 47.93305 \\
5 & 3.325356 & 52.74229 & 47.25771 \\
6 & 3.406541 & 50.28310 & 49.71690 \\
7 & 3.432596 & 51.03224 & 48.96776
\end{tabular}




\begin{tabular}{cccc}
8 & 3.461272 & 50.34396 & 49.65604 \\
9 & 3.470172 & 50.36933 & 49.63067 \\
10 & 3.478003 & 50.33858 & 49.66142 \\
\hline \hline \multicolumn{2}{l}{ Variance Decomposition of PERTUMBUHAN_EKONOMI: } & & \\
& & & PERTUMBUHAN \\
Period & S.E. & IPM & EKONOMI \\
\hline \hline 1 & 0.489242 & 1.434250 & 98.56575 \\
2 & 0.551352 & 21.79830 & 78.20170 \\
3 & 0.636092 & 17.40880 & 82.59120 \\
4 & 0.655950 & 21.16105 & 78.83895 \\
5 & 0.677273 & 21.58034 & 78.41966 \\
6 & 0.685902 & 21.51730 & 78.48270 \\
7 & 0.690647 & 22.23871 & 77.76129 \\
8 & 0.694512 & 21.99232 & 78.00768 \\
9 & 0.695660 & 22.24060 & 77.75940 \\
10 & 0.696989 & 22.21582 & 77.78418 \\
\hline \hline
\end{tabular}

\section{E. KESIMPULAN}

Setelah dilakukan analisa terhadap penelitian tersebut di atas, Penulis berkesimpulan sebagai berikut :

1. IPM dan Pertumbuhan Ekonomi berkaitan erat dan saling mempengaruhi. Peningkatan Pertumbuhan Ekonomi berpengaruh positif terhadap IPM. Dalam jangka panjang hubungan antara IPM dengan pertumbuhan ekonomi cenderung setabil namun jangka pendek cenderung menurun.

2. Pengujian kointegrasi Johansen's tampak nilai trace statistic > critical value pada tingkat keyakinan 5\%. Dengan demikian mengidentifikasikan kedua variabel saling berkointegrasi.

Saran : Perlu dilakukan kajian - kajian lanjutan dengan menggunakan variabel variabel diluar dari variabel yang digunakan dalam penelitian ini

\section{DAFTAR PUSTAKA}

Badan Pusat Statistik Provinsi Sumatera Utara. 2013. Beberapa Data Pokok Kondisi Kesejahteraan Rakyat dan Ekonomi Provinsi Sumatera Utara Tahun 2007 2012, Medan.

Badan Pusat Statistik Provinsi Sumatera Utara. 2013.Sumatera Utara dalam Angka 2013. Medan.

Gujarati, N. Damonar, 2003, Econometrika Dasar, Terjemahan. Jakarta Green, William H.2000, Econometric Analysis, Fourth Edition, New Jersey: Prentice Hal Inc.Nachrowi, 2006, Ekonometrika, LPFEUI, Jakarta.

Pratiwi, Eka. 2014. Analisis Pertumbuhan Ekonomi Ekonomi dan Indeks Pembangunan Manusia (IPM) Provinsi-Provinsi di Indonesia (Metode Kointegrasi), Skripsi, Fakultas Ekonomi dan Bisnis Universitas Sumatera Utara, Medan.

Pratomo, Wahyu Ario dan Paidi Hidayat. 2007. Pedoman Praktis Penggunaan Eviews dalam Ekonometrika, USU Press, Medan.

Tanjung, Hendri dan Devi, Abrista.2013. Metodologi penelitian Ekonomi Islam, Gramata Publishing, Jakarta. 